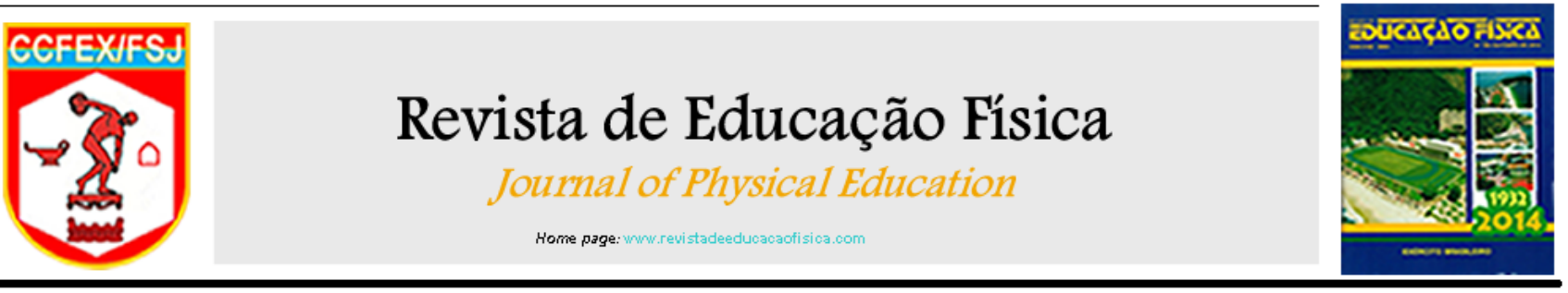

Resumo

\title{
Oxigenação muscular durante o exercício contrarresistência com restrição de fluxo sanguíneo no modo isocinético
}

Renato Naste Shirado Bsci, Cláudia Meirelles PhD

Introdução: 0 exercício com restrição de fluxo sanguíneo (RFS) consiste na aplicação de pressão nas extremidades proximais dos membros superiores ou inferiores. É sabido que este protocolo possibilita ganhos de força e hipertrofia, porém muito tem se questionado acerca dos mecanismos que contribuem fisiologicamente para os referidos ganhos.

Objetivo: Analisar a oxigenação muscular durante a restrição de fluxo sanguíneo no modo isocinético.

Métodos: Foram estudados dez voluntários, do sexo masculino (idade 18,6 \pm 0,5 anos; massa corporal $67,6 \pm 8,3 \mathrm{~kg}$; estatura $175,1 \pm 6,3 \mathrm{~cm}$; \% gordura 8,6 \pm 2.9). Foi aferida, por meio de ultrassonografia na artéria poplítea, a pressão de oclusão total $(161,0 \pm 16,3 \mathrm{mmHg})$ para que fosse utilizada a pressão de oclusão a $50 \%(80,5 \pm 8,3 \mathrm{mmHg})$ na execução das séries. 0 teste de força, realizado no modo isocinético, seguiu o seguinte protocolo: três séries de cinco repetições máximas; $50 \%$ RFS, velocidade angular de $60 \%$, com intervalo de um minuto entre as séries, modo concêntrico/concêntrico. Para monitorar a oxigenação muscular foi utilizada a espectroscopia no infravermelho próximo (NIRS). 0 tratamento estatístico mais importante utilizado foi a ANOVA $(2 \times 3$; primeiro fator condição e segundo fator teste - séries 1, 2 e 3) com medidas repetidas no segundo fator).

Resultados: A análise de variância (ANOVA) de duas entradas $(2 \times 3$; primeiro fator condição e segundo fator teste - série 1 , série 2 e série 3) com medidas repetidas nos dois fatores mostrou que não houve diferenças estatisticamente significativas de oxigenação muscular entre as condições e entre as séries.

Conclusão: Após monitoramento e análise dos resultados não foi possível verificar diferenças significativas entre as condições, o que sugere que mais estudos devem ser realizados para se chegar a uma resposta mais efetiva. 